\title{
ENTREVISTA COM ADRIANA LISBOA
}

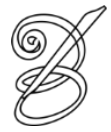 \\ Amanda Mendes Casal ${ }^{1}$ \\ (Mestranda em Estudos da Tradução - POSTRAD-UnB/Brasília/DF/Brasil) \\ amendescasal@yahoo.com.br
}

escritora e tradutora Adriana Lisboa nasceu no Rio de Janeiro e hoje vive nos
Estados Unidos. Estudou música na Uni-Rio e se especializou em Literatura
Brasileira (mestrado) e em Literatura Comparada (doutorado) pela UERJ. Seu primeiro romance, Os fios da memória, foi publicado em 1999, pela Editora Rocco, ao qual se seguiram Sinfonia em branco (2001), que recebeu o Prêmio José Saramago, Um beijo de colombina (2003), Rakushisha (2007) e Azul-corvo (2010), além de outros três livros infantojuvenis, Língua de trapos (2005), com o qual recebeu o prêmio de autora revelação pela Fundação Nacional do Livro Infantil e Juvenil, Contos populares japoneses (2008) e A sereia e o caçador de borboletas (2009). Seus livros foram traduzidos na Alemanha, França, Portugal, Romênia, Suécia, Sérvia, México e Argentina, entre outros países. Sua carreira de tradutora compreende escritores como Cormac McCarthy, Marilynne Robinson, Margaret Atwood, Emile Faguet, Amós Oz e Maurice Blanchot.

Você tem títulos traduzidos por editoras como Rocco, Ediouro, Nova Fronteira, Casa da Palavra, Alfaguara e Objetiva. Como você começou a traduzir? Você acredita que tantos convites para traduzir, vindos das mais diversas editoras, se devem a seu reconhecimento como escritora?

ADRIANA LISBOA: Quando comecei a traduzir, eu tinha apenas um livro publicado. Na época, era recém-formada pelo curso de Tradução de Daniel Brilhante de Brito, que escreveu uma carta de recomendação muito generosa. Fiz alguns samples de tradução e enviei para algumas editoras, mencionando também a minha publicação, que não sei até que ponto pesou (talvez desse às editoras uma certeza maior de que a tradutora em questão seria alguém com um domínio satisfatório da língua portuguesa, embora ter livro publicado não seja garantia de rigorosamente nada). A Ediouro me ofereceu meu primeiro trabalho, alguns meses depois. 
É possível dizer que sua atividade de tradutora é paralela à de escritora? Quais são, para você, os pontos de aproximação entre escrever e traduzir?

ADRIANA LISBOA: Estou abandonando a atividade de tradutora. Na verdade, há um ano já havia abandonado, mas reabri as portas para dois trabalhos que me interessavam - em seguida pretendo encerrar de vez a atividade. Não é fácil conciliar a escrita à tradução, mas no meu caso, não por que um texto interfira no outro. Existe a questão do tempo que a tradução exige, e do quanto o trabalho é desgastante intelectualmente e fisicamente (no final de 2011, tive dois episódios de LER).

Pela minha experiência, há criação na tradução - tem de haver, já que é impossível fazer dois idiomas coincidirem milimetricamente. O que não há é liberdade completa, claro - é criação dentro de uma moldura, criação intimamente costurada ao trabalho de outro autor, que deve ser sempre soberano. Mas se a fidelidade absoluta é impossível, o tradutor precisa saber arriscar, usando do seu bom senso.

Vamos falar um pouco de tradução imersa na ficção literária. Seu livro de 2007, Rakushisha, 214 compreende o traduzir desde antes de sua composição: o interesse por Bashô por meio dos haikais traduzidos por Manuel Bandeira no período em que você escrevia Um beijo de colombina, sua viagem a Kyoto para a escritura de seu romance; o encontro com o título Rakushisha; a composição da personagem Haruki, que vai ilustrar a tradução de um livro de Bashô, quando se vê afrontado por uma língua que "deveria” ser a sua; a viagem de Haruki e Celina para Kyoto. A ideia de traduzir, traduzir-se, como passar além ainda que o passo possa ser, como em Blanchot, um passo (não), parece fundamental em seu livro. Você poderia falar um pouco sobre sua experiência e também sobre a cultura oriental, talvez hoje na vizinhança da ocidental em virtude da incessante moção ou errância que, aliás, você também aborda em Azul-corvo (2010)?

ADRIANA LISBOA: Há também uma tradutora em Rakushisha, Yukiko, antiga amante de Haruki. É ela quem propõe o nome de Haruki como ilustrador do diário de Bashô. Ou seja: os dois se encontram no único lugar onde lhes é possível, agora - nas páginas do livro que ela traduz. Falar em oriente e ocidente tornou-se arriscado - e muitas vezes resvalamos nos clichês, quando tentamos. A errância, o deslocamento, a migração, a expatriação são fenômenos que me interessam, porque penso que deixam mais visível o caráter essencialmente passageiro de nossas próprias vidas. Para citar Vilém Flusser, "o cedro é estrangeiro no parque, eu sou estrangeiro na França, o homem é estrangeiro no mundo." 
Gosto de ser estrangeira - vivo nos Estados Unidos há seis anos, vivi na França antes disso, além de uma passagem de raspão por Kyoto como pesquisadora da Fundação Japão - mesmo quando sofro (e sofro) as inconveniências legais de não ser cidadã do país onde moro. Mas a experiência do imigrante legal, ilegal, do refugiado e de quem viaja por turismo são completamente distintas. Em Rakushisha, o personagem Haruki, que não é bem nenhuma dessas coisas, está em busca de entender esse outro, esse estranho que faz parte do seu próprio passado: o Japão. Mas, assim como a tradução perfeita é impossível, a "tradução" do Japão também o é para Haruki.

Suas obras foram traduzidas nos Estados Unidos, Sérvia, Suécia, Suíça, Itália, México, Argentina, França, ocasião em que Sinfonia em branco foi traduzida por Des roses rouge vif. Você conversa com seus tradutores ou acompanha o processo de tradução, quando possível? Considera importante o contato? Como tradutora, já recorreu a escritores que traduziu durante o processo de tradução?

ADRIANA LISBOA: Uma curiosidade, Sinfonia em branco sai na Alemanha este ano com outro título bem diferente: Der Sommer der Schmetterlinge. Quando possível, sim, acompanho as traduções dos meus livros. Lamentavelmente nem sempre, no passado, tive acesso a traduções mesmo de línguas que tenho condições de ler, e mais tarde, já publicados os livros, vi que poderia ter ajudado a evitar mais de um erro. Assim, hoje procuro insistir nisso, sem deixar que vire comportamento obsessivo... Claro que não tenho condições de avaliar um livro traduzido ao sérvio ou ao sueco, mas acho que o contato entre o autor vivo e o seu tradutor é sempre recomendável. Já recorri a vários autores que traduzi, no passado.

Quanto à tradução de Maurice Blanchot, o título Uma voz vinda de outro lugar é uma escolha sua ou a Rocco já tinha sugerido a tradução do termo "d'ailleurs" por "outro lugar"?

ADRIANA LISBOA: Já não me lembro se a sugestão foi minha ou da Rocco - você deve saber que em muitos casos a editora é quem escolhe o título, que nós, tradutores, nem sempre endossamos, mas nesse caso não me parece ruim. 
Mencionei o título porque li em um ensaio de João Camilo Penna, divulgado pela Rocco, antes da publicação oficial, a tradução de Uma voz vinda de longe. Você poderia comentar o que muda com a troca das expressões?

ADRIANA LISBOA: Talvez Uma voz vinda de longe soe melhor em português, pensando bem, mas não acho problemático o título Uma voz vinda de outro lugar. Não há diferenças essenciais de sentido, me parece. A tradução americana, por exemplo, é A Voice from Elsewhere (a tradutora é Charlotte Mandell, que também traduziu La part du feu - publicado como The Work of Fire - além de obras de Proust, Maupassant, Flaubert e Jean-Luc Nancy). Aliás, cheguei a trocar e-mails com ela em busca de esclarecer uma passagem de Uma voz... (já não me lembro qual).

Você consegue pensar nas motivações editorais que levam à escolha de uma escritora para traduzir Blanchot e, sobretudo, Une voix venue d'ailleurs, que é um livro que contém poemas de Des Forêts, Char e Celan?

ADRIANA LISBOA: Você sabe que traduzir é sempre correr riscos. Estando dos dois lados dessa equação - ou seja, tendo traduzido livros dos outros e tendo conversado com os tradutores dos meus próprios livros -, sei que estamos sempre trabalhando no território da aproximação. Às vezes há sacrifícios. Às vezes há perdas, às vezes ganhos.

Penso que a Rocco me convidou para traduzir o livro por interessar a eles o meu olhar específico de escritora de ficção. Recordo que boa parte da obra de Blanchot foi traduzida ao inglês por escritores como Paul Auster e Lydia Davis. Ou talvez a Rocco apenas confie no meu trabalho como tradutora, independentemednte do fato de eu ser ou não escritora - o que também deve ter acontecido quando me chamaram para traduzir um livro de poemas de Margaret Atwood, eu que não traduzo, habitualmente, poesia.

Há muitas diferenças em traduzir poema ou você acredita que o ato de linguagem criador é um ato poético, daí talvez a diluição das fronteiras entre prosa e poesia?

ADRIANA LISBOA: Acho que há muitas diferenças e foi um trabalho difícil e arriscado, no caso da minha experiência com os poemas de The Door, de Margaret Atwood. Acredito, sim, que o ato de linguagem criador é um ato poético, mas para mim - ainda que tenha começado a minha relação com a criação literária através da poesia, que arrisco, embora publicando só muito eventualmente, há quase 35 anos - é bastante diferente escrever (e traduzir) poesia, escrever (e traduzir) ficção. Existem sutilezas de ritmo, de sintaxe, próprias a cada uma, e o 
valor de cada palavra é distinto também. Penso que a poesia exige do criador e do tradutor uma precisão muito maior, quando a prosa se acolchoa em sua extensão. Se nos apropriarmos por um instante da aproximação que faz Cortázar entre conto/fotografia e romance/filme, eu diria talvez que o romance é um filme de longa-metragem, o conto um curta e o poema, sim, uma fotografia, um instantâneo. E cada um tem suas estratégias próprias, mesmo quando as fronteiras parecem diluídas.

Vamos refletir um pouco mais sobre "traição", lembrando-nos do adágio italiano traduttore tradittore, citado por Antoine Berman, em L’Épreuve de l'étranger, como parte de um discurso sobre a tradução sob a perspectiva da condição ancilar. Você poderia comentar este excerto de Philippe Soupault, em seu prefácio a Prince Igor?

"La traduction n'est une trahison que lorsqu'elle prétend, comme la photographie, reproduire la réalité. Ce serait vouloir décider à l'avance qu'un texte n'a ni reliefs, ni harmoniques, ni couleurs, ni surtout rythme".

ADRIANA LISBOA Paulo Henriques Britto, que tem todo o meu respeito e toda a minha admiração como poeta, contista e tradutor, faz um comentário que julgo cirúrgico sobre a questão do tradutor traidor: "A afirmação de que traduzir é trair é fruto de um impulso que pode ser resumido na expressão 'ou tudo ou nada' (...) A meta do trabalho do tradutor é, ou deve ser, a meu ver, a transparência - a reprodução na língua B de todos os efeitos textuais de um original na língua A. Isso, naturalmente, é impossível, já que os recursos dos dois idiomas não coincidem, e a intenção do autor do original é inatingível, e o tradutor não consegue evitar se colocar na tradução.” O excerto de Philippe Soupault me parece dizer algo parecido: não há como reproduzir, digamos, fotograficamente, a realidade do texto original no texto traduzido. Então, falar em tradução como traição parece inexato, quando qualquer tradução é apenas a melhor aproximação possível. A traição, se existe, se dá quando o tradutor se esquece do seu compromisso com o original e corre mais riscos do que deveria, emprestando ao texto o que não estava nele de saída. Essa é a temeridade da expressão «transcriação » de Haroldo de Campos, a meu ver. Nem tanto ao céu, nem tanto ao mar.

Em Uma voz vinda de outro lugar, você parece ter aproveitado seu espaço paratextual, assinalando algumas de suas escolhas tradutórias. Utilizar esse espaço, para você, é essencial ao traduzir? Você acredita que as editoras interditam a utilização desse espaço pelo tradutor? Destaco alguns desses momentos: na página 35, há a indicação de nota em 
"SENTENÇA de nascimento". Nela, você escreve: "No original, ARRÊT de naissance, que tanto significa 'pausa/paralisação de nascimento' quanto 'sentença de nascimento'. [N. da T.] Na página 68, você traduz "inação", mas apresenta entre colchetes o termo désoeuvrement.

ADRIANA LISBOA A opção por inserir algumas notas de rodapé só foi feita por se tratar de um livro de ensaio. Nos muitos livros de ficção que já traduzi sempre evitei as notas, a não ser em casos em que não havia outra saída. Certas editoras nem mesmo aceitam notas de rodapé em textos de ficção, o que acho louvável.

Não desgosto de désoeuvrement entre colchetes, mas essa é a solução fácil, me parece. A princípio o tradutor deveria buscar um equivalente em sua língua, não acha? (ocorre-me rapidamente o Dasein de Heidegger como uma exceção disso que acabei de dizer, entre muitas outras!) Mantendo-se o désoeuvrement em francês complexifica-se o léxico Blanchot, o que talvez não seja um problema. Mas não posso deixar de pensar, por exemplo, na clareza dos termos freudianos das Ich, das Es e das Über-Ich que viraram na tradução para o inglês os lamentáveis e herméticos ego, id e superego (adotados no Brasil em decorrência disso).

218 Désoeuvrement é uma palavra óbvia para qualquer falante de francês, mas não faz sentido algum para um falante de português.

Por outro lado, claro que o leitor de Blanchot não é um leitor despreparado. E com isso continuamos com a eterna negociação, não é?

Gostaria de relevar que tanto arrêt quanto désoeuvrement são termos constantes na obra de Blanchot. A tradutora Ana Maria de Alencar traduziu o récit L'Arrêt de mort por Pena de morte. Para você, essa é uma tradução "acertada" ou "aceitável” mesmo que saibamos que com ela perderemos a suspensão da morte, a impossibilidade da morte, que frequentemente aparece em Blanchot? O que você pensa sobre a tradução de João Moura Jr. de désoeuvrement por não obrar, em A conversa infinita 3: A ausência de livro?

ADRIANA LISBOA: A "pena de morte" não me parece fazer jus ao termo original em francês, e o "não obrar," embora me soe correto, não soa bem. Désoeuvrement é uma palavra tão bonita em francês, e "não obrar" parece passar longe - mas essa é a escritora em mim falando. Mais uma vez estamos diante de negociações e de escolhas que quase sempre serão insatisfatórias.

O texto de Blanchot não implica somente a tarefa de traduzir um texto propriamente autoral, mas também várias referências a outros autores que, por vezes, sofrem mutações 
significativas no texto de Blanchot. No caso de O último a falar, os poemas de Celan são estilhaçados e, por vezes, os estilhaços de vários poemas constroem um novo poema. Como você vê a tradução do fragmento? De outro modo, você acredita que a escritalescritura fragmentária imputa à tradução a necessidade de ser repensada?

ADRIANA LISBOA: Com relação à tradução do fragmento, e se ela representa uma necessidade de se repensar a tradução, eu mais uma vez diria que traduzir é um grande ato de humildade (ou deveria ser), e que sem dúvida nos encontramos muitas vezes em encruzilhadas radicais. Como traduzir, hoje, um romance do século XIX? Como traduzir esse mesmo romance daqui a cem anos? São sempre aproximações. Se fragmentos de um poema são utilizados ao longo de um ensaio, é preciso que na tradução os versos façam sentido tanto no texto que deles se apropriou como autonomamente, no poema de que se originaram. Não é tarefa simples e sem dúvida exige um cuidado redobrado.

Para completar, eu diria que em casos como Une voix... cabe à editora realizar uma cuidadosa revisão técnica do livro, o que, suponho, tenha acontecido. Já que sabem não ser eu uma especialista em Blanchot. No passado traduzi, para a mesma Rocco, o ensaio Eating Animals, de Jonathan Safran Foer, e eu mesma sugeri um revisor técnico de meu conhecimento e confiança, para garantir que a minha escolha de termos estivesse correta em português (ainda que eu seja bastante familiar com o tema).

Já que você menciona sua familiaridade com o tema do livro de Jonathan Safran Foer, lembrei-me de ter lido uma nota na imprensa na ocasião em que você se manifestou contra a campanha publicitária da Mastercard, que divulgou a frase "Não ter nenhum amigo vegetariano: não tem preço." Você menciona que é vegetariana e participa de organizações de defesa dos animais, como a PETA (People for the Ethical Treatment of Animals). Sua tradução, pela Rocco, Comer animais, me faz lembrar algumas das ideias dos Estudos Culturais acerca das expressões minoritárias. Você acredita que foi escolhida como tradutora por suas inclinações pessoais? De modo mais geral, que nos permite pensar, por exemplo, na teoria queer, como você vê a coautoria do tradutor no sentido de sua manifestação por meio de escolhas no texto traduzido?

ADRIANA LISBOA: Eating Animals foi um dos poucos casos na minha carreira de tradutora em que escolhi o livro e me ofereci para traduzi-lo. À época, a Rocco estava ainda negociando a compra dos direitos autorais com a agente do autor. E essa escolha específica teve tudo a ver 
com as minhas inclinações pessoais. A questão ética das nossas relações com os animais é das mais importantes no mundo contemporâneo, na minha opinião -, pois fala não apenas do respeito ao outro, ao diferente, e ao direito inalienável que esse outro tem de buscar a felicidade, como também se relaciona diretamente com a ecologia (a criação de animais pela indústria de alimentos é, hoje, catastrófica para o meio ambiente) e com o aproveitamento dos recursos naturais de um planeta limitado. O livro de Jonathan Safran Foer seria traduzido de todo modo, mas foi um privilégio ter sido a responsável por esse trabalho, e mais uma oportunidade, para mim, de trazer à tona esse assunto importantíssimo. Aliás, o título Eating animals foi, também, difícil de traduzir, e a opção final, Comer animais, ficou a cargo da editora. Eu havia sugerido algo semelhante ao título italiano (Se niente importa: perché mangiamo gli animali?), mas a editora fez outra opção. Que afinal talvez tenha sido a melhor - mais limpa.

${ }^{1}$ Currículo Lattes em: <http://buscatextual.cnpq.br/buscatextual/visualizacv.do?id=K4456006H0〉. 